\title{
Efficacy of some anthelmintics against the swimbladder nematode Anguillicola crassus of eel Anguilla anguilla under saltwater conditions
}

\author{
A. Geets ${ }^{1}$, E. W. Liewes ${ }^{2}$, F. Ollevier ${ }^{1}$ \\ ${ }^{1}$ Laboratory for Ecology and Aquaculture, Zoological Institute, Naamsestraat 59, B-3000 Leuven, Belgium \\ ${ }^{2}$ HVA-Fish Farm Development bv, PO Box 503, 1110 AM Diemen, The Netherlands
}

\begin{abstract}
Six anthelmintic drugs, Ivermectin, Closantel, Safewormer, Masoten, Oxfendazole and L-Levamisol $\mathrm{HCl}$, were screened for their efficacy against Anguillicola crassus, a swimbladder nematode of European eel Anguilla anguilla. All experiments were carried out under saltwater conditions. Of the 6 drugs, L-Levamisole $\mathrm{HCl}$ used in a bath treatment gave the most promising results. Evaluation of the curative dose of L-Levamisole $\mathrm{HCl}$ showed that a long-term treatment ( $6 \mathrm{~d}$ ) with $20 \mathrm{mg} \mathrm{l}^{-1}$ was far more effective than a short-term treatment $(24 \mathrm{~h})$. Dosages lower than $20 \mathrm{mg} \mathrm{l}^{-1}$ showed a lower efficacy against Anguillicola crassus. However, even with a long-term, high-dosage treatment, some recovery of adult nematodes with sublethal damage and/or migration of viable juveniles into the swimbladder lumen could not be excluded When examined $35 \mathrm{~d}$ after treatment, the percentage of mobile adults had increased, while a decrease in percentage of dead worms was noticed compared to values obtained immediately after treatment.
\end{abstract}

\section{INTRODUCTION}

Anguillicola crassus Kuwahara, Niimi \& Itagaki, 1974 is a swimbladder nematode of japanese eel Anguilla japonica, indigenous to eastern Asia. For some years now, $A$. crassus has been found in European eel Anguilla anguilla (Paggi et al. 1982, Van Banning et al. 1985. Molnar 1986, De Charleroy et al. 1987).

The nematode spread quickly through the wild eel stock in Europe due to importation of eels from the Far East, restocking of infested eels and natural dispersion (Canestri-Trotti 1987, Belpaire et al. 1989). Wildcaught fingerling eels, used for stocking several commercial eelfarms in Europe, were also possibly infected (De Charleroy et al. 1990). Consequently, problems in commercial eel culture arose, and pathological effects induced by the parasite were investigated. Naturally infected eels seemed to show more severe lesions than experimentally infected eels (Haenen et al. 1989). Elevated mortalities of 10 to $20 \%$ and loss of growth in eels by 20 to $30 \%$ were reported (Liewes et al. 1987). Therefore, studies on possible treatments against the nematodes were strongly urged (Ghittino et al. 1989).

Basically, 2 ways of controlling anguillicolosis were proposed. Firstly, prophylactic methods were used, whereby bodies of water are treated to eliminate the intermediate hosts (copepods) so that the life cycle of the parasites cannot be completed. Complete eradication of the copepods seems virtually impossible, however (De Charleroy pers. comm.). Therefore, therapeutic treatment of infested eels with anthelmintics was considered.

Taraschewski et al. (1988) examined the effects of 5 nematocidal drugs on Anguillicola crassus adults and preadults, under freshwater conditions: Levamisole. $\mathrm{HCl}$, Metrifonate, Febendazole, Mebendazole and Ivermectin. Three different methods of administration were evaluated: force-feeding, bath treatments and intramuscular injections. Levamisole $\mathrm{HCl}$ seemed to be the most effective, and bath treatment with $1 \mathrm{mg} 1^{-1}$ per $24 \mathrm{~h}$ led to a complete cure. Hartmann (1989) investigated the long-term effects of various dosages of Levamisole on the different developmental stages. Adults and preadults showed considerable loss of vitality for 3 wk after therapy. Eggs and newly hatched larvae showed no reaction to the drug. According to Hartmann (1989), a single treatment with Levamisole under freshwater conditions seemed to be ineffective 
since some nematodes were able to regenerate after suffering sublethal damage. The results mentioned above were all obtained with eels in freshwater. In the present investigation, the efficacy of 6 anthelmintic drugs (including Levamisole) on $A$. crassus was evaluated under saltwater conditions in a commercial eel farm.

\section{MATERIALS AND METHODS}

Parasitized eels. The experiments were conducted at an eel farm in the Netherlands which used a saltwater recirculation system (salinity 28 to $30 \mathrm{ppt}$ ) for stocking and rearing the eels. Naturally infested eels Anguilla anguilla (weight 15 to $30 \mathrm{~g}$ ) from the IJsselmeer (The Netherlands) were used for the experiments.

Reinfection of the eel stock did not occur since saltwater is lethal for the larval stages of Anguillicola crassus, and no marine crustaceans are known to function as first intermediate hosts for this nematode (De Charleroy et al. 1989). Since heavily infested eels died and there was no reinfection of the stocked fish, the percentage of infestation of the stock of eels used for experiments declined from $78 \%$ in July 1987 to $35 \%$ in March 1988. The mean number of adult nematodes per eel during the experiments was 2.85 , which represents a rather low level of infection.

Selection of antiparasitical drugs. Since no anthelmintics specific for fish were known at the time our research was conducted, anthelmintics developed for veterinary use in farm animals were evaluated. Drugs were selected using the following criteria: the drug should (1) be effective against haematophagous nematodes; (2) attain a substantial level in the blood; (3) be easy to administer and be known to have a low toxicity; (4) be easily resorbed through the digestive tract or the skin; (5) be known to leave no unacceptable residues.

On this basis, 6 drugs were retained (asterisks indicate the names used in this report): (1) Ivermec (1\% solution of Ivermectine ${ }^{*}$; M.S.D.-Agrivet); (2) Flukiver drench $15 \%$ solution of Closantel"; Janssen Pharmaceutica); (3) Safewormer powder (containing a mixture of pytanteltartrate and flubenol; Colombo, Hoevelaken); (4) Masoten" powder (Bayer Leverkusen); (5) Syanthic $\left(2.265 \%\right.$ solution of Oxfendazole ${ }^{*}$ Syntex International, Animal Health Division); (6) Ripercol $\left(10 \%\right.$ solution of L-Levamisole $\mathrm{HCl}{ }^{\circ}$; Janssen Pharmaceutica).

Treatment methods. In most experiments, bath treatments were used. This proved to be the best method, since eels that did not feed could also be treated. In addition, a force-feeding experiment was carried out with Closantel.

Information on use of the drugs for treatment of fishes was minimal. Therefore, each drug was screened first on its toxicity to eels. Next, its efficacy against Anguillicola crassus was investigated. For the forcefeeding experiment, the given dosage was based on the prescription for farm animals.

Experimental conditions. Since the eels were stocked in a saltwater recirculation system, most treatments were carried out in saltwater (salinity 28 to 30 ppt). Only for the bath treatment with Closantel was freshwater used, since this drug seemed to be insoluble in saltwater. About $1 \mathrm{wk}$ before the experiment with Closantel started, the eels were transferred to freshwater to adapt to the freshwater environment.

For the first set of experiments, on toxicity and efficacy of the drugs (see Table 1), a minimum of 10 eels per treatment was used. They were kept in aerated aquaria containing $8 \mathrm{l}$ saltwater. In addition, aquaria (40 l) with about 30 eels per experimental condition were used in experiments to evaluate the curative dose of L-Levamisole $\mathrm{HCl}$ (see Table 2). In both these sets of experiments, the eels were killed and examined immediately after treatment.

In a final experiment, in which long-term effects of LLevamisole $\mathrm{HCl}$ on adult nematodes were evaluated, 2 tanks of $30 \mathrm{~m}^{3}$ were stocked with 334 and $322 \mathrm{~kg}$ of eels respectively (mean individual weight $=32 \mathrm{~g}$ ). One tank was treated on 6 consecutive days with $20 \mathrm{mg} \mathrm{I}^{-1}$ L-Levamisole $\mathrm{HCl}$. The other tank was used as a control. The water in both tanks was drained and changed daily during treatment. Care was taken not to flush water containing L-Levamisole $\mathrm{HCl}$ into the recirculation system. In this experiment, 30 eels were investigated from each tank $35 \mathrm{~d}$ after finishing the therapy, in order to evaluate the long-term effects of the treatment. During treatment the eels were not fed.

Parasitological examination. After all treatments, eels were anaesthetized and killed with an overdose of Hypnodil (20 $\mathrm{mg} \mathrm{l}^{-1}$ ) before the swimbladder was removed for examination. The swimbladder was dissected and examined for Anguillicola crassus. Adults, preadults, larval stage 1 (L1, surrounded with egg membrane) and larval stage 2 (L2, hatched and very mobile, without egg membrane and with a long thin tail) were distinguished. Since we used drugs during the experiments which cause paralysis in nematodes (e.g. L-Levamisole $\cdot \mathrm{HCl}$ ) 3 different states of vitality of adult and preadult $A$. crassus were distinguished: 'mobile', 'immobile' (worms paralyzed but still intact) and 'dead' (worms disintegrated).

The mobility of Anguillicola crassus adults and preadults was determined as follows: (1) the nematode was put in a drop of freshwater, or (2) the bottom of the petri dish containing the nematode was slightly heated. If the nematode was intact but did not respond to these stimuli by showing wriggling movements, it was consi- 
dered 'immobile'. Occasionally, worms which had disintegrated were found; these were recorded as dead.

The mobility of larval stages 1 and 2 was examined with a light microscope. When there was any doubt about the vitality (especially for stage L1) they were kept in petri dishes with freshwater for 1 to $3 \mathrm{~d}$ and examined again. Under these conditions, viable larvae hatch and are very mobile.

\section{RESULTS}

\section{Toxicity of drugs to eels}

Ivermectin and Closantel, administered by means of a bath treatment, were found to be toxic in low concentrations. For Ivermectin, concentrations between $2 \times$ $10^{-4} \mathrm{mg} \mathrm{l}^{-1}$ and $15 \times 10^{-3} \mathrm{mg} \mathrm{l}^{-1}$ were tested. Closantel was tested in concentrations between $25 \times 10^{-2} \mathrm{mg} \mathrm{l}^{-1}$ and $100 \mathrm{mg} \mathrm{l}^{-1}$. Ivermectin induced mortality in $50 \%$ of the eels at a concentration of $2 \times 10^{-4} \mathrm{mg} \mathrm{l}^{-1}$ after $24 \mathrm{~h}$. The $\mathrm{LC}_{50}$ value for Closantel, screened in freshwater, was $2.5 \mathrm{mg} \mathrm{l}^{-1}$ after $24 \mathrm{~h}$. The drench form of Closantel, however, was not toxic when a dose of $10 \mathrm{mg} \mathrm{kg}^{-1}$ body weight was administered orally in the force-feeding experiment. Masoten was found not to be toxic in low concentration $\left(0.5 \mathrm{mg} \mathrm{l}^{-1}\right)$ as a bath treatment. Concentrations above $2.0 \mathrm{mg} \mathrm{l}^{-1}$ should not be used, according to the instructions for farm animals distributed with the drug.
Safewormer, Oxfendazole and L-Levamisole $\cdot \mathrm{HCl}$ were not found to be toxic.

Considering the high toxicity of Ivermectin and Closantel when administered by bath, no further experiments on their effectiveness against Anguillicola crassus were carried out using bath treatments. However, since Closantel administered by force-feeding did not seem to be toxic, further experiments using this method were conducted.

\section{Efficacy of anthelmintics against Anguillicola crassus}

In the first set of experiments, 5 anthelmintic drugs were tested for their efficacy against Anguillicola crassus: Safewormer, Closantel, Masoten, Oxfendazole and L-Levamisole. HCl ( Table 1).

Safewormer, even in high concentrations, seemed ineffective against the nematodes. Closantel (forcefed), Masoten and Oxfendazole had only a slight effect on Anguillicola crassus adults in comparison with LLevamisole $\mathrm{HCl}$. The short-term bath treatment $(24 \mathrm{~h})$ with L-Levamisole $\mathrm{HCl}\left(20 \mathrm{mg} \mathrm{l}^{-1}\right.$ ) left only $15 \%$ of the worms mobile, while no mobile worms were found in the long-term bath treatment $\left(6 \mathrm{~d}, 20 \mathrm{mg} \mathrm{l}^{-1}\right)$. Considering the difficulties in administering Closantel (force-feeding), the rather high toxicity of Masoten and the low effectiveness of Oxfendazole and Safewormer, no further investigations were performed with these products.

Table 1. Experiments on efficacy of 5 anthelmintic drugs against Anguillicola crassus adults infecting Anguilla anguilla Concentrations in $\mathrm{mg} \mathrm{l}^{-1}$ unless otherwise indicated. BW: Body weight; Inf.: infested; Mob.: mobile nematodes; Imm.: immobile but intact nematodes; Dead: decomposed nematodes; Total: \% Imm. + \% Dead

\begin{tabular}{|c|c|c|c|c|c|c|c|c|c|c|}
\hline Drug & Method & Time & Conc. & $\begin{array}{l}\text { No. of } \\
\text { eels }\end{array}$ & $\%$ Inf. & $\begin{array}{l}\text { No. of } \\
\text { worms }\end{array}$ & $\%$ Mob. & $\%$ Imm. & $\%$ Dead & Total \\
\hline \multirow[t]{3}{*}{ Safewormer } & Bath & $5 \mathrm{~d}$ & 0 & 10 & 100 & 33 & 94.0 & - & - & 6.0 \\
\hline & Bath & $5 \mathrm{~d}$ & 800 & 10 & 80 & 17 & 94.0 & - & - & 6.0 \\
\hline & Bath & $5 \mathrm{~d}$ & 2400 & 10 & 70 & 24 & 88.0 & - & - & 12.0 \\
\hline \multirow[t]{2}{*}{ Control $^{a}$} & - & $24 \mathrm{~h}$ & 0 & 10 & 20 & 7 & 100.0 & 0.0 & 0.0 & 0.0 \\
\hline & - & $6 \mathrm{~d}$ & 0 & 10 & 60 & 13 & 92.3 & 0.0 & 7.7 & 7.7 \\
\hline Closantel & $\begin{array}{l}\text { Force- } \\
\text { feeding }\end{array}$ & $6 \mathrm{~d}$ & $\begin{array}{c}10 \mathrm{mg} \\
\mathrm{kg}^{-1} \mathrm{BW}\end{array}$ & 20 & 40 & 17 & 64.7 & 11.8 & 23.5 & 35.3 \\
\hline \multirow[t]{2}{*}{ Masoten } & Bath & $24 \mathrm{~h}$ & 0.5 & 10 & 50 & 11 & 90.9 & 0.0 & 9.1 & 9.1 \\
\hline & Bath & $6 \mathrm{~d}$ & 0.5 & 10 & 50 & 17 & 82.4 & 11.7 & 5.9 & 17.6 \\
\hline \multirow[t]{2}{*}{ Oxfendazole } & Bath & $24 \mathrm{~h}$ & 20 & 10 & 50 & 14 & 71.4 & 0.0 & 28.6 & 28.6 \\
\hline & Bath & $6 \mathrm{~d}$ & 20 & 10 & 30 & 7 & 85.7 & 0.0 & 14.3 & 14.3 \\
\hline \multirow[t]{2}{*}{ Levamisole } & Bath & $24 \mathrm{~h}$ & 20 & 10 & 60 & 20 & 15.0 & 65.0 & 20.0 & 85.0 \\
\hline & Bath & $6 \mathrm{~d}$ & 20 & 10 & 40 & 7 & 0.0 & 100.0 & 0.0 & 100.0 \\
\hline
\end{tabular}


Since L-Levamisole. $\mathrm{HCl}$ is easy to administer (bath treatment) and has a very low toxicity for eels $\left(\mathrm{LC}_{50}=\right.$ $250 \mathrm{mg} \mathrm{l}^{-1}, 24 \mathrm{~h}$; Taraschewski et al. 1988), and considering the rather promising results with this product, all further experiments were focused on the use of this drug as a treatment for anguillicolosis.

\section{Evaluation of curative dose of L-Levamisole $\cdot \mathrm{HCl}$}

Further experiments were set up to determine the optimal curative dose of L-Levamisole $\cdot \mathrm{HCl}_{\text {, }}$ using bath treatments in a saltwater system.

Firstly, a short-term bath treatment ( 24 h, 1 administration) with $20 \mathrm{mg} \mathrm{l}^{-1} \mathrm{~L}$-Levamisole $\mathrm{HCl}$ was compared with a long-term treatment ( $6 \mathrm{~d}, 6$ administrations) (Table 1). The dose of $20 \mathrm{mg} \mathrm{l}^{-1}$ was selected based on our previous findings which showed that higher doses of L-Levamisole $\cdot \mathrm{HCl}$ did not result in higher immobilization of Anguillicola crassus (data not shown). The long-term treatment clearly gave better results than the short-term treatment. When treated with $20 \mathrm{mg} \mathrm{l}^{-1}$ L-Levamisole $\mathrm{HCl}$ for 6 consecutive days, all eels were free of mobile $A$. crassus adults. In contrast, $15 \%$ of the nematodes were still mobile when only a short-term treatment of $24 \mathrm{~h}$ with the same concentration was carried out.

Secondly, long-term bath treatments ( $6 \mathrm{~d}$ ) with varying concentrations of L-Levamisole $\mathrm{HCl}(2.5,5.0,10.0$ and $20 \mathrm{mg} \mathrm{l}^{-1}$ ) were tested to determine if concentrations lower than $20 \mathrm{mg} \mathrm{l}^{-1}$ would be sufficient to paralyze the nematodes (Table 2). Treatments of $6 \mathrm{~d}$

Table 2. Evaluation of curative dose of L-Levamisole $\mathrm{HCl}$, when used in long-term bath treatment ( 6 d), for Anguillicola crassus infecting Anguilla anguilla. Column headings as in Table 1

\begin{tabular}{|rrrrrrrr|}
\hline $\begin{array}{c}\text { Conc. } \\
\text { (mg l }\end{array}{ }^{-1}$ ) & $\begin{array}{c}\text { No. } \\
\text { of } \\
\text { eels }\end{array}$ & $\begin{array}{r}\% \\
\text { Inf. }\end{array}$ & $\begin{array}{c}\text { No. } \\
\text { of } \\
\text { worms }\end{array}$ & $\begin{array}{c}\% \\
\text { Mob. }\end{array}$ & $\begin{array}{c}\% \\
\text { Imm }\end{array}$ & $\begin{array}{c}\% \\
\text { Dead }\end{array}$ & Total \\
\hline 0.0 & 26 & 46.2 & 26 & 84.6 & 0.0 & 15.4 & 15.4 \\
2.5 & 33 & 30.3 & 14 & 21.4 & 64.3 & 14.3 & 78.6 \\
5.0 & 24 & 31.4 & 24 & 33.3 & 41.7 & 25.0 & 66.7 \\
10.0 & 31 & 19.4 & 13 & 23.1 & 69.2 & 7.7 & 76.9 \\
20.0 & 30 & 30.0 & 20 & 5.0 & 50.0 & 45.0 & 95.0 \\
\hline
\end{tabular}

with concentrations lower than $20 \mathrm{mg} \mathrm{l}^{-1}$ showed a much lower efficacy against Anguillicola crassus. When treated with $20 \mathrm{mg} \mathrm{l}^{-1}$ L-Levamisole $\mathrm{HCl}, 95 \%$ of $A$. crassus adults were immobile or dead, whereas only up to $78.6 \%$ of the adults were immobilized or dead after treatment with lower concentrations.

Unfortunately, the prevalence of preadult and larval stages during the Levamisole experiments was so low that the impact of the drug on these nematode develop. mental stages could not be determined clearly in this study

\section{Long-term effect of L-Levamisole $\cdot \mathrm{HCl}$ treatment on Anguillicola crassus adults}

In a final experiment, the long-term effects of $\mathrm{L}$ Levamisole $\mathrm{HCl}$ treatment on adult nematodes were evaluated. Thirty-five days after treatment, 30 eels were examined for viability of Anguillicola crassus adults. Again, L-Levamisole $\mathrm{HCl}$ demonstrated effectiveness: when treated, $85 \%$ of the adult $A$. crassus were paralyzed or dead, compared with only $20 \%$ in the control group (Table 3).

Table 3. Evaluation of long-term effects of L-Levamisole $\mathrm{HCl}$ treatment $\left(20 \mathrm{mg} \mathrm{l} \mathrm{l}^{-1}, 6 \mathrm{~d}\right.$ ) on Anguillicola crassus infecting Anguilla angurlla. Abbreviations as in Table 1

\begin{tabular}{|lcccc|}
\hline & $\begin{array}{c}\text { Nematodes checked } \\
\text { immediately after } \\
\text { treatment } \\
\text { Control }\end{array}$ & $\begin{array}{c}\text { Nematodes checked } \\
\text { 3reated }\end{array}$ & $\begin{array}{c}\text { 35 d after } \\
\text { treatment } \\
\text { Control }\end{array}$ & Treated \\
\hline No. of eels & 36 & 40 & 30 & 30 \\
\% Inf. & 53 & 35 & 36 & 36 \\
No. of worms & 39 & 27 & 20 & 20 \\
\% Mob. & 88.5 & 2.5 & 80.0 & 15.0 \\
$\%$ Imm. & 0.0 & 75.0 & 0.0 & 70.0 \\
\% Dead & 11.5 & 22.5 & 20.0 & 15.0 \\
a Results from 2 samples combined & & \\
\hline
\end{tabular}

These results were compared with those from the former experiments, in which the nematodes were checked immediately after treatment. In all experiments used for this comparison, the same L-Levamisole $\mathrm{HCl}$ therapy was given (20 $\mathrm{mg} \mathrm{l}^{-1}, 6 \mathrm{~d}$ ) - only the period between therapy and examination differed. Immediately after treatment only $2.5 \%$ of the adults were found mobile, while this value reached $15 \%$ when checked $35 \mathrm{~d}$ after treatment. The percentage of dead nematodes declined, however: while $22.5 \%$ of the nematodes were found dead when checked immediately after therapy, only $15 \%$ were found dead $35 \mathrm{~d}$ after treatment. Thus, disintegration of the paralyzed worms apparently did not increase.

\section{DISCUSSION}

Out of 6 anthelmintics which were tested as possible drugs against Anguillicola crassus under saltwater conditions, L-Levamisole $\mathrm{HCl}$ seemed the most effective. The other drugs were either found to be too toxic for 
eels (Ivermectin and Closantel, bath treatment) or too difficult to administer (Closantel, force-feeding), or had too low an efficacy against $A$. crassus [Safewormer, Masoten, Oxfendazole (bath treatments), Closantel (force-feeding)]. Taraschewski et al. (1988) also noted the high toxicity of Ivermectin. They used intramuscular injections, but the eeis died within $2 \mathrm{wk}$, whereas the worms survived. These investigators found $\mathrm{L}$ Levamisole $\mathrm{HCl}$ to be the most effective drug for treatment of eels in a freshwater environment.

To assess the optimal curative dose of L-Levamisole $\mathrm{HCl}$, it was necessary for us to focus on various dosages and times of exposure. Taraschewski et al. (1988) also tested different dosages and exposure times. Although their results served as a useful basis for further research, caution had to be exercised in drawing conclusions because of the low number of eels used per experimental condition. Our experiments showed that a long-term bath treatment of 6 consecutive days with $20 \mathrm{mg} \mathrm{l}^{-1}$ L-Levamisole $\mathrm{HCl}$ was much more effective than a short-term treatment ( $24 \mathrm{~h})$ with the same concentration. When different dosages were tested in a long-term treatment of $6 \mathrm{~d}$, all dosages lower than 20 $\mathrm{mg}^{\mathrm{l}^{-1}}$ showed lower efficacy against Anguillicola crassus. Under saltwater conditions, a bath treatment of 6 consecutive days with $20 \mathrm{mg} \mathrm{l}^{-1}$ seemed to give optimal results. This contradicts results of Taraschewski et al. (1988) for freshwater experiments in which a $24 \mathrm{~h}$ bath treatment of $1 \mathrm{mg} \mathrm{l}^{-1}$ led to a complete cure. According to Hartmann (1989), who also conducted his study in freshwater, a higher concentration of L-Levamisole $\mathrm{HCl}\left(5 \mathrm{mg} \mathrm{l}^{-1}, 24 \mathrm{~h}\right)$ worked faster and effected higher short-term nematode mortality than a lower dosage $(2$ $\mathrm{mg} \mathrm{l}^{-1}, 24 \mathrm{~h}$ ), which was in accordance with our findings. The use of a high dosage $\left(20 \mathrm{mg} \mathrm{l}^{-1}\right)$, such as in our experiments, will obviously cause high short-term mortality among $A$. crassus adults. However, one should be cautious not to draw quick conclusions about the optimal curative dose, because the effect of a therapy, checked immediately after treatment, can differ completely when rechecked some weeks later. Hartmann (1989) showed that some of the nematodes are able to regenerate after suffering sublethal damage. He noticed an increase in the number of intact nematodes about 3 wk after treatment with LLevamisole $\cdot \mathrm{HCl}$. This would be due to the recovery of preadults and adults and the migration of surviving juveniles into the lumen of the swimbladder. As indicated by our experiments, long-term treatment $(6 \mathrm{~d})$ with a high dosage $\left(20 \mathrm{mg} \mathrm{l}^{-1}\right)$ will most probably have a long and severe impact on the viable nematodes, more nematodes will suffer lethal damage and, subsequently, recovery from sublethal damage will be much lower than after a short-term, low-dosage treatment.

Nonetheless, the percentage of mobile worms found
$35 \mathrm{~d}$ after treatment was higher than when checked immediately after therapy. These results suggest that, even after long-term high-dosage treatment, a degree of recovery and migration of viable juveniles into the swimbladder lumen cannot be excluded.

Furthermore, the number of dead worms $35 \mathrm{~d}$ after treatment was lower than that immediately after treatment. Hartmann (1989) explained this decrease in dead, disintegrated worms as a result of ejection of their remains from the eels through the ductus pneumaticus. This could not, however, be verified in our experiments, since we used commercial tanks with a high density of eels for this experiment.

Our results show that, although a long-term treatment using a high dosage of L-Levamisole $\cdot \mathrm{HCl}$ seems quite efficacious against adult Anguillicola crassus initially, it will probably be ineffective if not followed by subsequent treatments. In accordance with Hartmann's recommendation (1989), a second treatment scheduled about $3 \mathrm{wk}$ after the first, and possibly other treatments later at longer time intervals, seem advisable. The advantage of a saltwater system (as in our experiments) over a freshwater system is that no reinfection of the eel stock occurs, since nematode larvae do not survive saline conditions and no suitable intermediate hosts are present.

Although L-Levamisole $\mathrm{HCl}$ seems to be a very promising drug in the treatment of anguillicolosis, more data should be gathered about the residues of the drug in the fish flesh, and its effects on consumability of the eels, before it can be used in commercial eel farms on a large scale.

\section{LITERATURE CITED}

Belpaire, C., De Charleroy, D., Thomas, K., Van Damme, P., Ollevier, F. (1989). Effects of eel restocking on the distribution of the swimbladder nematode Anguillicola crassus in Flanders, Belgium. J. appl. Ichthyol. 5: 151-153

Canestri-Trotti, G. (1987). Occurrence of the nematode Anguillicola crassa Kuwahara, Niimi \& Itagaki, 1974 in eels from the Po delta, Italy. Bull. Eur. Ass. Fish Path. 7 (5): 109-111

De Charleroy, D., Grisez, L., Thomas, K., Belpaire, C., Ollevier, F. (1990). The life cycle of Anguillicola crassus. Dis. aquat. Org. 8: 77-84

De Charleroy, D., Thomas, K., Belpaire, C. (1987). Problems concerning the species determination, biology and diagnostical methods of Anguillicola, a swimbladder nematode in European eel (Anguilla anguilla L.). EIFAC (European Inland Fisheries Advisory Commission, FAO) Working Party on Eel, Bristol, UK, 13-16 April 1987, p. 7

De Charleroy, D., Thomas, K., Belpaire, C., Ollevier, F. (1989) The viability of free living larvae of Anguillicola crassus. J. appl. Ichthyol. 5: 154-156

Ghittino, C., Ghittino, F., Marin De Mateo, M. (1989). Aggiornamento sull anguillicolosi, una frequente aerocistile parassitaria delle anguille. Adjournment on anguillicolosis, a frequent parasitic aerocystitis of eel. Riv. ital. Acquac. 24: 125-136 
Haenen, O. L. M., Grisez, L., De Charleroy, D., Belpaire, C., Ollevier, F. (1989). Experimentally induced infections of European eel Anguilla anguilla with Anguillicola crassus (Nematoda, Dracunculoidea) and subsequent migration of larvae. Dis aquat. Org. 7: 97-101

Hartmann, F. (1989). Investigations on the effectiveness of Levamisol as a medication against the eel parasite Anguillicola crassus (Nematoda). Dis. aquat. Org. 7: 185-190

Liewes, E. W., Schaminee-Main, S. (1987). Onderzoek aalparasiet vordert. Aquacultuur 2 (4): 5-17

Molnar, K. (1986). Solving parasite related problems in cultured freshwater fish. Proc. 6th ICOPA, Australian Academy of Science, Canberra, 319-326

Responsible Subject Editor: W. Körting, Hannover Germany
Paggi, L., Orecchia, P., Minervini, R., Matiucci, S. (1982). Sulla comparsa di Anguillicola australiensis Johnston et Mawson 1940 (Dracunculoidea: Anguillicolidae) in Anguilla anguilla del Lago di Bracciano. Parassitologia Roma 24 (2/ 3): $139-144$

Taraschewski, H., Renner, C., Mehlhorn, H. (1988). Treatment of fish parasites. 3. Effects of levamisole $\mathrm{HCl}$, metrifonate, febendazole, mebendazole and ivermectin on Anguillicola crassus (nematodes) pathogenic in the air bladder of eels. Parasitol. Res. 74: 281-289

Van Banning, P., Heermans, W., Van Willingen, J.A. (1985). Anguillicola crassa, een nieuwe aalparasiet in de Nederlandse wateren. Visserij 38 (6/7): 237-240

Manuscript first received: October 8,1991 Revised version accepted: April 30, 1992 